\title{
Effect of monoclonal antibodies directed against Candida albicans cell wall antigens on the adhesion of the fungus to polystyrene
}

\author{
Rosario San Millan, ${ }^{1}$ Pilar A. Ezkurra, ${ }^{1}$ Guillermo Quindós, ${ }^{1}$ \\ Raymond Robert, ${ }^{2}$ Jean Marcel Senet ${ }^{2}$ and Jose Pontón ${ }^{1}$ \\ Author for correspondence: Jose Pontón. Tel: +3444647700 ext. 2746. Fax: +3444648152 .
e-mail: oipposaj@lg.ehu.es
}

1 Departamento de Inmunología,

Microbiología y

Parasitología, Facultad de

Medicina y Odontología,

Universidad del País Vasco,

Apartado 699, E-48080

Bilbao, Vizcaya, Spain

2 Laboratoire

d'Immunologie-

Parasitologie, Section

Pharmacie, UER des

Sciences Médicales et

Pharmaceutiques,

16 bd Daviers, 49100

Angers, France

\begin{abstract}
The adhesion of Candida albicans to polystyrene and the effect of three monoclonal antibodies (mAbs) reactive with $C$. albicans cell wall surface antigens on this process was assessed in vitro with several $C$. albicans strains. In the absence of mAbs, adhesion of $\mathrm{C}$. albicans to polystyrene increased in parallel with germ-tube formation. However, the growth of the strains in the yeast phase at $25^{\circ} \mathrm{C}$ or the use of an agerminative mutant inhibited adhesion to polystyrene. Serotype A and B strains showed similar kinetics of adhesion to polystyrene and no statistically significant differences in germination or adhesion were observed when strains from the two serotypes were compared. The three mAbs had different effects on both germination and adhesion of $C$. albicans. mAb 3D9 showed no influence on either germination or adhesion to polystyrene in two $C$. albicans strains. mAb B9E decreased both adhesion (45.6\%) and filamentation (52.6\%), and mAb $21 E 6$ decreased filamentation $(34.0 \%)$ but enhanced adhesion by $23 \cdot 3 \%$. This enhancement was also observed with the agerminative mutant and it was dose-dependent. It was not related to the binding capacity of the MAb to polystyrene nor to an increase in cell surface hydrophobicity of the antibody-treated cells. In conclusion, both growth phases of $C$. albicans can adhere to polystyrene, although the conditions for this process seem to be different in each phase. The two types of adhesion of $C$. albicans to polystyrene might have a role in the colonization of medical implants. The disparate effects shown by mAbs directed against cell wall mannoproteins of $\mathrm{C}$. albicans on the adhesion of the fungus to polystyrene should be taken into consideration when designing strategies to block the adhesion of $C$. albicans to plastic materials with mAbs.
\end{abstract}

Keywords: Candida albicans, adhesion to polystyrene, filamentation, germ tubes, monoclonal antibodies

\section{INTRODUCTION}

Medical implants such as catheters, prosthetic cardiac valves, joint replacements and dental prosthesis have improved the health status of many patients. However, these devices can become colonized by different microorganisms to form a biofilm and establish a reservoir for chronic inoculation and dissemination of microbial cells (Costerton et al., 1987). Different studies have demonstrated the capacity of Candida albicans to adhere to plastic materials (Hawser \& Douglas, 1994; Klotz et al., 1985; McCourtie \& Douglas, 1981; Minagi et al., 1985) and factors such as the surface hydrophobicity, elec- trostatic forces and germ tube formation seem to play a key role in the adhesion process (Kennedy et al., 1989; Kimura \& Pearsall, 1980; Klotz et al., 1985; Rotrosen et al., 1985). The yeast-mycelium transition, which may be associated with C. albicans pathogenicity (Cutler, 1991), results in a molecular reorganization of the cell wall that may facilitate the adhesion of the fungus to biomaterials by expressing a fibrillar layer associated with the outer part of the cell wall. In fact, we have identified four cell wall mannoproteins of $>200,200,68$ and $60 \mathrm{kDa}$ that remained attached to polystyrene when the $C$. albicans cells were removed (Tronchin et al., 1988).

Attachment of $C$. albicans to medical implants may be a 
critical step in the initiation of colonization and infection. Knowledge of the mechanisms for attachment of $C$. albicans to the materials of such devices could lead to the development of a novel class of antifungal agents whose mechanism of action would be to block adhesion of the fungus. In this paper we have studied the effect of different monoclonal antibodies (mAbs) on the adhesion of $C$. albicans to polystyrene.

\section{METHODS}

Fungal strains and culture conditions. Candida albicans serotype A (NCPF 3153), obtained from the National Collection of Pathogenic Fungi (Bristol, UK) was used in most experiments. In some experiments, C. albicans 1066 (Tronchin et al., 1988) and C. albicans CA2, a germ-tube-deficient strain kindly supplied by Dr A. Cassone (Istituto Superiore di Sanita, Rome, Italy) were also used. The agerminative mutant is an echinocandin-resistant mutant of the parental strain 3153 (Bistoni et al., 1986). To compare the adhesion and filamentation of serotype $\mathrm{A}$ and $\mathrm{B}$ strains, the strains $C$. albicans NCPF 3153 serotype A, C. albicans NCPF 3156 serotype $B$, and 28 clinical isolates (14 of each serotype) were used. The strains were maintained at $4{ }^{\circ} \mathrm{C}$ on slants containing $20 \mathrm{~g}$ glucose, $10 \mathrm{~g}$ yeast extract and $20 \mathrm{~g}$ agar $1^{-1}$. Yeast cells and germ tubes were grown in medium 199 (Sigma) as previously described (Pontón \& Jones, 1986).

Serotype testing. C. albicans serotypes were distinguished on the basis of reactions of agglutination (serotype $\AA$ ) or nonagglutination (serotype B) with Candida-check antiserum 6 (Iatron) according to the manufacturer's instructions.

mAbs. The three mAbs, 21E6, 3D9 and B9E, were produced by standard methods. Briefly, BALB/c mice were immunized by subcutaneous injections of: (i) germ tube fibrinogen binding factor (3D9); (ii) germ tube cell wall components adhered to polystyrene Petri dishes (21E6); or (iii) a partially purified antigen of $260 \mathrm{kDa}$ from a germ tube cell wall extract eluted from SDS-PAGE gels (B9E) (Ponton et al., 1993). mAbs were purified from ascites fluid by affinity chromatography on an anti-mouse IgM (Sigma) coupled to an Affi-Gel 10 column (BioRad). Purified antibodies were dialysed against PBS before use.

Adherence assay. The adhesion of $C$. albicans cells to polystyrene was studied by a previously described method (Tronchin et al., 1988). Briefly, yeast cells in the stationary phase were inoculated in medium $199, \mathrm{pH} 6.7$, at a final concentration of $5 \times 10^{6}$ celis $\mathrm{ml}^{-1}$ and incubated for $140 \mathrm{~min}$ at $37^{\circ} \mathrm{C}$ in 35 - or 120-mm-diameter tissue culture polystyrene Petri dishes (Greiner) containing, respectively, 0.65 or $50 \mathrm{ml}$ of the yeast cell suspension. Germination was quantified by counting, every $20 \mathrm{~min}$, both the total number of cells and the number of yeast cells bearing germ tubes, using a phase-contrast microscope with a graticule mounted in the focus of the ocular. For each Petri dish, 12 fields (each $0.64 \mathrm{~mm}^{2}$ ) were counted, and the percentage of germ tubes per field was calculated by the equation: $\%$ filamentation $=$ (no. of yeast cells bearing germ tubes/total no. of cells) $\times 100$. Petri dishes were then rinsed with distilled water to dislodge all the loosely adherent yeast cells. The fungal cells which adhered to the plastic surface were counted as described above. Results were expressed as a percentage of the whole cell population according to the equation: $\%$ adhesion $=($ no. of adhered cells $/$ total no. of cells $) \times 100$. All values quoted represent mean values derived from four independent assays.

In one experiment, the cells were grown in an Erlenmeyer flask containing medium 199 . Germ tubes were induced at $37^{\circ} \mathrm{C}$ with shaking and yeast cells were grown at $25^{\circ} \mathrm{C}$. After 40 min of growth, the cells were washed with medium 199 at $4{ }^{\circ} \mathrm{C}$, counted in a haemocytometer and transferred to polystyrene Petri dishes at a final concentration of $5 \times 10^{6}$ cells $\mathrm{mi}^{-1}$. The Petri dishes were incubated at $24^{\circ} \mathrm{C}$ for $40 \mathrm{~min}$ and the adhesion was quantified as described above. The controls consisted of cells incubated in Petri dishes for $40 \mathrm{~min}$ at both $37^{\circ} \mathrm{C}$ and $25^{\circ} \mathrm{C}$.

Isolation of germ tube cell wall components adhered to polystyrene. After a $3 \mathrm{~h}$ incubation, the Petri dishes were washed with distilled water and the germ tubes were removed from the plastic surface with a cell lifter (Costar Europe). Plates were washed again with distilled water and the cell wall mannoproteins that remained adhered to the Petri dishes were solubilized with $0 \cdot 1 \mathrm{M} \mathrm{NaOH}$ for $5 \mathrm{~min}$ at room temperature. After the treatment, the extracts were dialysed against distilled water for $48 \mathrm{~h}$ and lyophilized.

Effect of mAbs on germination and adherence. To determine the effect of the mAbs on adherence, the adhesion assay described above was slightly modified. Yeast cells were inoculated in medium 199 containing $154 \mu \mathrm{g} \mathrm{mAbs} \mathrm{ml} l^{-1}$. Control media were supplemented with the same volume of sterile distilled water. Germination and adhesion were quantified as described above.

SDSPAGE and Western blotting. SDS-PAGE was performed by the method of Laemmli (1970) in a minigel system (Bio-Rad). The total amount of protein loaded per lane was $1 \mu \mathrm{g}$ for each extract. Electrophoresis was carried out in $10 \%$ (w/v) acrylamide at $200 \mathrm{~V}$ for $45 \mathrm{~min}$. Standard molecular mass markers were from Bio-Rad. Subsequently, the gels were either stained with silver nitrate or were electrophoretically transferred to a nitrocellulose membrane (Bio-Rad) for $30 \mathrm{~min}$ at $60 \mathrm{~V}, 10 \mathrm{~W}$ and $5 \mathrm{~mA} \mathrm{~cm}^{-2}$ using the Fast Blot System (Biometra). After the transfer, the nitrocellulose membranes were blocked in $10 \%$ $(\mathrm{w} / \mathrm{v})$ nonfat dry milk in Tris-buffered saline (TBS-Milk), washed in TBS and incubated with the mAbs (3D9 diluted $1: 5$, 21E6 diluted $1: 5$ and B9E diluted 1:10, all in TBS-Milk), washed, and incubated with peroxidase-labelled, affinitypurified goat anti-mouse IgM (Sigma). Immunoreactive bands were visualized after staining for $30 \mathrm{~min}$ with a substrate solution $[0.05 \%(\mathrm{w} / \mathrm{v})$ 4-chloro-1-naphthol (Sigma) and $0.015 \%(\mathrm{v} / \mathrm{v}) \mathrm{H}_{2} \mathrm{O}_{2}$ in TBS]. In some experiments, the antigens present on the nitroceilulose membrane were treated with $50 \mathrm{mM} \mathrm{NaIO}$ as described by Sundstrom \& Kenny (1984) and incubated with MAb $21 \mathrm{E} 6$ as described above.

ELISA. The binding capacity of mAbs $21 \mathrm{E} 6$ and $\mathrm{B} 9 \mathrm{E}$ to polystyrene was studied by ELISA. Briefly, wells of polystyrene plates (Greiner) were coated with $100 \mu \mathrm{l}$ of the mAbs (150 or $75 \mu \mathrm{g} \mathrm{ml}^{-1}$ ) suspended in medium 199 and incubated for $60 \mathrm{~min}$ at $37^{\circ} \mathrm{C}$. Plates were blocked by adding $200 \mu \mathrm{I}$ PBS containing $10 \%$ nonfat dry milk and $0.05 \%$ Tween 20 (PBSBT) to each well for $1 \mathrm{~h}$ at $37^{\circ} \mathrm{C}$. They were then incubated with peroxidaseconjugated, goat anti-mouse IgM (Sigma) diluted 1:2000 in PBS-milk for $1 \mathrm{~h}$ at $37^{\circ} \mathrm{C}$. Plates were washed with PBS and $100 \mu \mathrm{l}$ of a solution containing $0.05 \%$ o-phenylendiamine dihydrochloride (Sigma) and $40 \mu \mathrm{l} 30 \%(\mathrm{v} / \mathrm{v}) \mathrm{H}_{2} \mathrm{O}_{2}$ in $0.15 \mathrm{M}$ phosphate/citrate buffer ( $\mathrm{pH} 5.0$ ) were added to each well. Plates were incubated in the dark at room temperature for $30 \mathrm{~min}$. The reaction was stopped with $50 \mu \mathrm{l} 1 \mathrm{M} \mathrm{H}_{2} \mathrm{SO}_{4}$ and $A_{490}$ was read with a Titertek Multiscan.

Cell surface hydrophobicity. To test if the pretreatment of $C$. albicans 3153 cells with mAbs $21 \mathrm{E} 6$ and $\mathrm{B} 9 \mathrm{E}$ modified the cell surface hydrophobicity, we incubated the $C$. albicans cells at $37^{\circ} \mathrm{C}$ for $40 \mathrm{~min}$ in the presence of $\mathrm{mAbs} 21 \mathrm{E} 6$ and $\mathrm{B} 9 \mathrm{E}$, and then the pretreated cells were incubated with latex beads as 
proposed by Hazen \& Hazen (1987). The experiments were performed in duplicate.

Statistics. Student's $t$ test was used to assess the significance of differences between means in adhesion and filamentation of serotype $A$ and $B$ strains. Data were considered significant at $P<0.05$. When using the $\mathrm{mAbs}$, the percentage of bound cells and standard error was calculated for each Petri dish. The appropriate percentage and variance was then obtained considering all the independent assavs. The hrpothesis of two treatments being equal was tested $(\alpha=0 \cdot 05)$ using the normal approximation to the distribution of the observed percentage. Results are presented as means \pm SEM.

\section{RESULTS}

\section{Adherence of $C$. albicans strains to polystyrene}

The kinetics of adherence of several $C$. albicans strains to polystyrene was initially explored at two temperatures. All strains showed similar kinetics; as illustrated in Fig. 1 for $C$. albicans 3153 serotype $A$, adhesion at $25^{\circ} \mathrm{C}$ was very low and it did not significantly change during the time studied. At $37^{\circ} \mathrm{C}$, however, there was an increase in the adhesion of the fungus in parallel with germ tube formation. Maximum levels of filamentation $(96.6 \%)$ and adhesion $(77 \cdot 7 \%$ ) were reached at $140 \mathrm{~min}$. To assess if serotype $A$ and $B$ strains showed differences in filamentation and/or adhesion to polystyrene, 15 serotype $A$ and 15 serotype $B$ strains were incubated for $140 \mathrm{~min}$ in polystyrene Petri dishes. No statistically significant differences were observed between serotypes in either germination (serotype A $87 \cdot 9 \pm 3 \cdot 4 \%$ versus serotype $B$ $84.3 \pm 3.1 \%$ ) or adhesion to polystyrene (serotype $A$ $58 \cdot 1 \pm 5 \cdot 6 \%$ versus serotype $\mathrm{B} 58 \cdot 0 \pm 3 \cdot 7 \%$. The relationship between germ tube formation and adhesion to polystyrene observed in all the strains studied was confirmed using an agerminative mutant, CA2. As expected, no filamentation and consequently no adhesion to polystyrene was observed with this strain (data not shown).

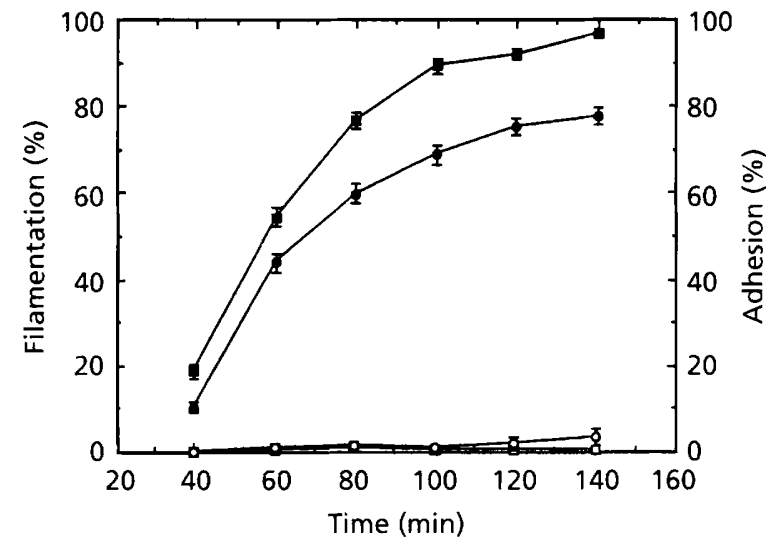

Fig. 1. Kinetics of germination $(\square, \square)$ and adhesion $(O, 0)$ to polystyrene of $C$. albicans 3153 (serotype A) incubated at $37{ }^{\circ} \mathrm{C}$ $(\square, 0)$ or $25^{\circ} \mathrm{C}(\square, \bigcirc)$. Data points represent the means of quadruplicate determinations \pm SEM.

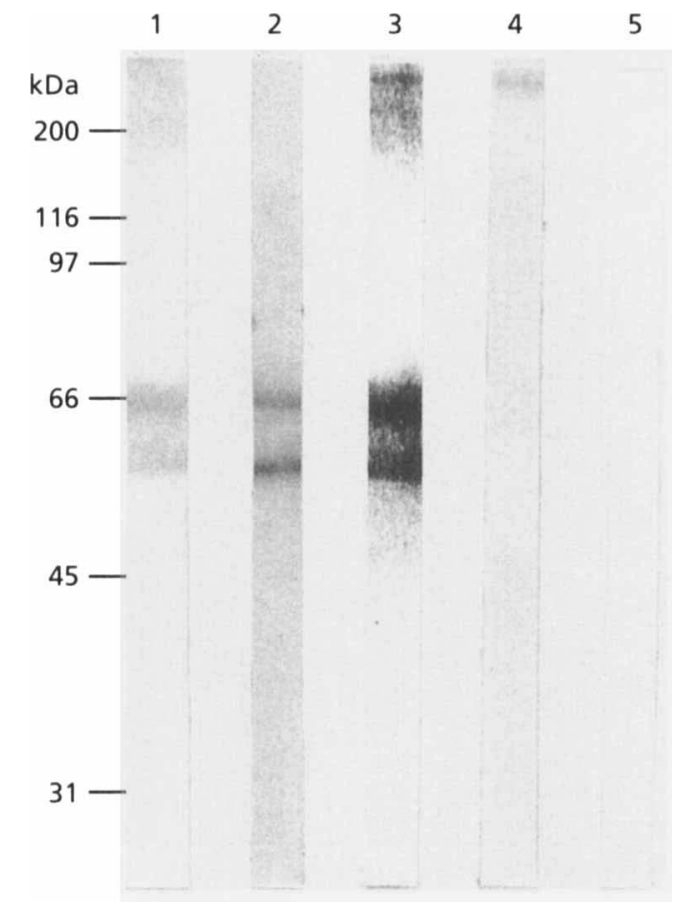

Fig. 2. Western blots of $10 \%$ slab gels loaded with $\mathrm{NaOH}$ extracts from fibrillar adhesins stained with silver nitrate (lane 1) and mAbs 21E6 (lanes 2 and 3), B9E (lane 4) and 3D9 (lane 5). In lane 3 , antigens present on the nitrocellulose membrane were treated with sodium periodate before the incubation with the antibody. Positions of molecular mass standards are shown on the left.

In an attempt to separate germination from adhesion, the germ tubes were first induced by incubating cells in an Erlenmeyer flask for $40 \mathrm{~min}$ at $37^{\circ} \mathrm{C}$; the cells were then transferred to polystyrene Petri dishes and allowed to adhere for $40 \mathrm{~min}$ at $25^{\circ} \mathrm{C}$ to avoid further germ tube growth. Pre-formed germ tubes adhered to polystyrene at a percentage higher than that shown by germ tubes induced directly in polystyrene Petri dishes $(19 \cdot 68 \pm 2 \cdot 04 \%$ versus $10 \cdot 4 \pm 1 \cdot 3 \%)$. Differences in adhesion may be related to the different percentage filamentation observed in the two systems, since germ tubes induced in Erlenmever flasks with shaking showed a higher percentage filamentation $(47.75 \pm 2.57 \%$, versus $18.7 \pm 1.69 \%$ for germ tubes induced in polystyrene Petri dishes). However, yeast cells grown in Erlenmeyer flasks at $25^{\circ} \mathrm{C}$ showed very low adhesion when transferred to polystyrene Petri dishes $(0 \cdot 16 \pm 0 \cdot 23 \%)$.

\section{Reactivity of C. albicans adhesins with mAbs}

We have previously shown that $C$. albicans germ tubes adhere to polystyrene through cell wall fibrillar adhesins that remain attached to polystyrene after the removal of adherent germ tubes (Tronchin et al., 1988). SDS-PAGE analysis of those adhesins showed three components of $\geqslant 200,68$ and $60 \mathrm{kDa}$ after silver staining (Fig. 2). When the reactivity of these mannoproteins with different $\mathrm{mAbs}$ was studied, $\mathrm{mAb} 21 \mathrm{E} 6$ stained the antigens of 68 and 


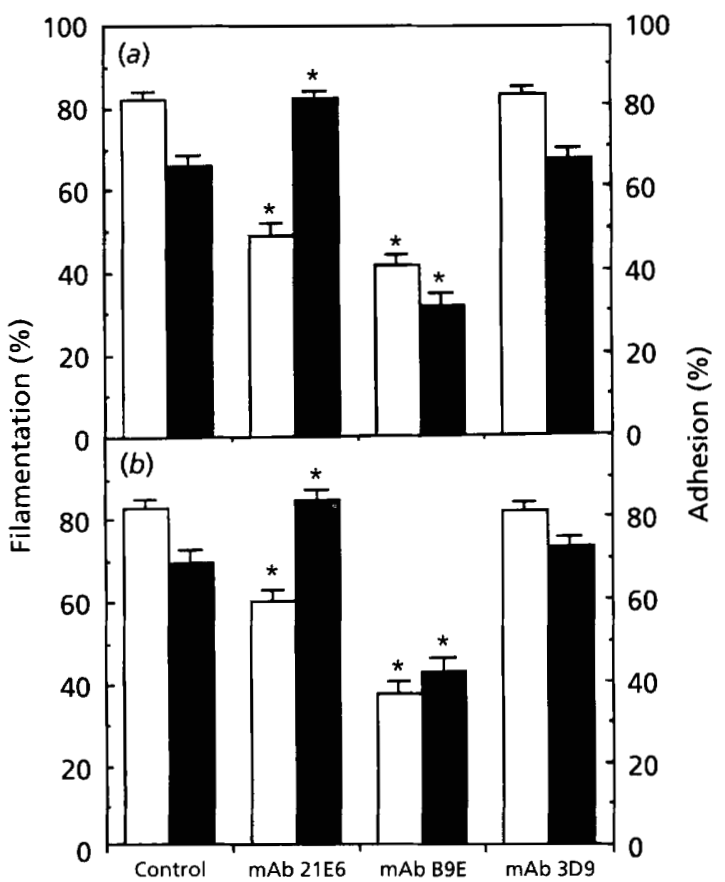

Fig. 3. Effect of incubation with mAbs 21E6, B9E and 3D9 on germination $(\square)$ and adhesion to polystyrene ( $\square$ ) of $C$. albicans 3153 (a) and C. albicans 1066 (b) incubated at $37{ }^{\circ} \mathrm{C}$ for $80 \mathrm{~min}$. Results represent the means of triplicate determinations \pm SEM. * Results were significantly different $(P<0.001)$ from control values without mAbs (by the normal approximation to the distribution of the observed percentage).

$60 \mathrm{kDa}$, but it also reacted with the high molecular mass antigens after periodic acid oxidation of the mannoproteins. In this case, two antigens of $>200$ and $200 \mathrm{kDa}$ were observed. $\mathrm{mAb} \mathrm{B} 9 \mathrm{E}$ only reacted with the $>200 \mathrm{kDa}$ antigen and $\mathrm{mAb}$ 3D9 did not show any reactivity with the fibrillar adhesins.

\section{Influence of mAbs on adhesion}

The effect of the mAbs on the adhesion of $C$. albicans strains 3153 and 1066 to polystyrene was initially studied after incubation at $37^{\circ} \mathrm{C}$ for $80 \mathrm{~min}$. When compared to the controls without $\mathrm{mAbs}, \mathrm{mAb} \mathrm{B} 9 \mathrm{E}$ significantly reduced the adhesion of the strains to polystyrene $(52.5 \%$ and $38.7 \%$, respectively) (Fig. 3) and produced a statistically significant decrease in filamentation in both strains $(50 \cdot 3 \%$ and $55 \cdot 0 \%)$. mAb 3D9 caused no statistically significant differences in either filamentation or adhesion in the two strains studied compared with controls. However, $\mathrm{mAb} 21 \mathrm{E} 6$ enhanced the adhesion of C. albicans 3153 and 1066 by $24.95 \%$ and $21.67 \%$, respectively. The enhancement of adhesion observed with $\mathrm{mAb} 21 \mathrm{E} 6$ was largely independent of germ tube induction, since this $\mathrm{mAb}$ reduced the filamentation at ali times studied (Fig. 4). The enhancement of adhesion was greater when the levels of filamentation were low. Thus, incubation of $\mathrm{C}$. albicans 3153 cells at $37^{\circ} \mathrm{C}$ for $40 \mathrm{~min}$ in the presence of $\mathrm{mAb} 21 \mathrm{E} 6$ enhanced the adhesion to

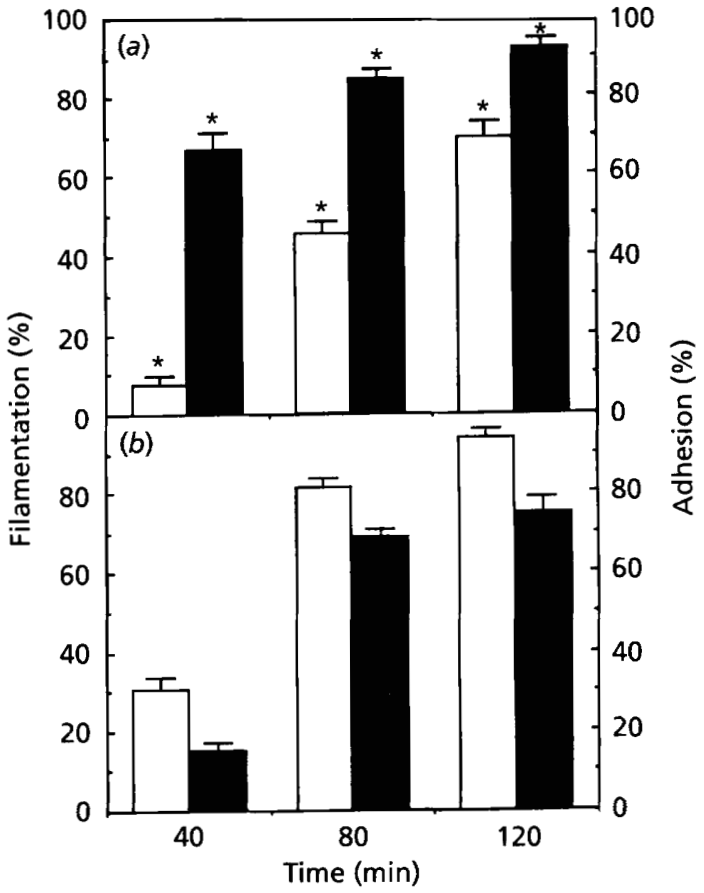

Fig. 4. Kinetics of germination $(\square)$ and adhesion to polystyrene (1) of C. albicans incubated at $37^{\circ} \mathrm{C}$ for 40,80 and $120 \mathrm{~min}$ in the presence (a) or absence (b) of mAb 21E6. Data points represent the means of triplicate determinations \pm SEM. * Values were significantly different $(P<0.001)$ from control values without mAb 21E6 (by the normal approximation to the distribution of the observed percentage).

$353.7 \%$ of the control level, whereas only a moderate increase in adhesion (26-38\%) was observed at longer times of germ tube induction. The low correlation between adhesion to polystyrene and filamentation in $C$. albicans cells pretreated with $\mathrm{mAb} 21 \mathrm{E} 6$ was confirmed with the agerminative mutant, for which similar levels of adhesion $(70 \cdot 7 \pm 2 \cdot 7,77 \cdot 9 \pm 2 \cdot 2$ and $77 \cdot 3 \pm 2 \cdot 5 \%)$ were observed at 40,80 and $120 \mathrm{~min}$ of incubation at $37^{\circ} \mathrm{C}$. This experiment clearly showed that, in the presence of $\mathrm{mAb} 21 \mathrm{E} 6$, yeast cells can also adhere to polystyrene. To study the effect of the dose of $\mathrm{mAb} 21 \mathrm{E} 6$ on the adherence of $C$. albicans 3153 to polystyrene, different dilutions of the $\mathrm{mAb}$ were tested. When the $\mathrm{mAb}$ was tested at a concentration of $154 \mu \mathrm{g} \mathrm{ml} \mathrm{m}^{-\mathbf{1}}, 7 \cdot 9 \pm 1 \cdot 3 \%$ filamentation and $63 \cdot 1 \pm 2 \cdot 3 \%$ adhesion were observed. Incubation of C. albicans with the $\mathrm{mAb}$ at a 10 -fold lower concentration increased both filamentation $(19 \cdot 4 \pm 2 \cdot 1 \%)$ and adhesion $(77 \cdot 8 \pm 2 \cdot 0 \%)$. However, still lower concentrations of $\mathrm{mAb} 21 \mathrm{E} 6$ showed no effect on filamentation although there was a dose-dependent decrease in adhesion.

The effect of mAb 21E6 on the adhesion to polystyrene Petri dishes of yeast cells and germ tubes previously grown in Erlenmeyer flasks for $40 \mathrm{~min}$ was investigated. $\mathrm{mAb} 21 \mathrm{E} 6$ enhanced the adhesion of the pre-formed germ tubes to polystyrene Petri dishes by $382.8 \%$ compared with the control without $\mathrm{mAb}(75.35 \pm 2.43 \%$ versus $19 \cdot 68 \pm 2 \cdot 04 \%$ ). Yeast cells grown in Erlenmeyer flasks at 
$25^{\circ} \mathrm{C}$ and then incubated with the $\mathrm{mAb} 21 \mathrm{E} 6$ in polystyrene Petri dishes showed low levels of adhesion to polystyrene $(6 \cdot 31 \pm 1 \cdot 33 \%)$.

The different effects of mAbs B9E and 21E6 on adhesion of $C$. albicans to polystyrene were not related to the binding capacity of the mAbs to polystyrene since, when tested at the same concentration $\left(150 \mu \mathrm{g} \mathrm{m} \mathrm{m}^{-1}\right), \mathrm{mAbs}$ $\mathrm{B} 9 \mathrm{E}$ and $21 \mathrm{E} 6$ showed a similar binding to polystyrene ( $A_{490} 0 \cdot 110 \pm 0 \cdot 005$ and $0 \cdot 106 \pm 0 \cdot 005$, respectively).

\section{Influence of incubation with mAbs on cell surface hydrophobicity}

To assess if the enhancement of adherence to polystyrene observed in $C$. albicans cells incubated with mAb $21 \mathrm{E} 6$ was related to an increase in cell surface hydrophobicity we measured the cell surface hydrophobicity of $C$. albicans cells before or after incubation with $\mathrm{mAbs} 21 \mathrm{E} 6$ and B9E. Control cells without $\mathrm{mAbs}$ showed a cell surface hydrophobicity of $16.89 \pm 2.44 \%$. Cells pretreated with $\mathrm{mAb}$ B9E were more hydrophobic than the controls $(27 \cdot 42 \pm 2 \cdot 87 \%)$. Conversely, pretreatment with $\mathrm{mAb}$ 21E6 rendered the cells more hydrophilic than the controls $(7 \cdot 75 \pm 1 \cdot 50 \%)$.

\section{DISCUSSION}

Among the factors shown to influence the adhesion of $C$. albicans to plastic, germ tube formation may be particularly important since adherent germ tubes have a fibrogranular layer that contains mannoproteins adhesive to polystyrene (Tronchin et al., 1988). Hyphal growth also seems to be an important factor in biofilm formation and Hawser \& Douglas (1994) have shown that a mutant unable to grow in the hyphal phase had a decreased capacity for biofilm formation on plastic catheters, whereas a related mutant unable to grow in the yeast phase gave values for biofilm formation similar to those of the wild-type. The results presented in this paper confirm a role for germ tube formation in the adhesion of $C$. albicans to polystyrene, since germ tubes, when induced, adhered to polystyrene and adhesion increased as the percentage of filamentation increased. In contrast, when the fungus was grown in the yeast form, either by growing strain 3153 at $25^{\circ} \mathrm{C}$ or by using the agerminative mutant CA2 grown at 25 or $37^{\circ} \mathrm{C}$, there was no adhesion to polystyrene.

Factor 6, an epitope in the cell wall mannan responsible for serotype specificity, is another factor that has been implicated in adhesion of C. albicans to oral cells; serotype $B$ or factor-6-deficient mutants have reduced adherence compared with serotype A strains (Miyakawa et al., 1989, 1992). However, Kennedy et al. (1992) studied the adhesion to polystyrene of yeast cells from several serotype $B$ isolates and observed that, in general, serotype $B$ was more adhesive to plastic than serotype $A$. In our study, adhesion kinetics were very similar in both $C$. albicans serotype $A$ and $B$ strains. The similarities in adhesion to polystyrene observed between the two serotypes may be related to the participation of germ tubes in adhesion to polystyrene, since both serotype $A$ and B germ tubes express antigen 6 (Barturen $e t$ al., 1995; Poulain et al., 1983).

Adhesion of $C$. albicans germ tubes to polystyrene seems to be mediated by cell wall fibrillar adhesins of $>200$, 200, 68 and $60 \mathrm{kDa}$ (Tronchin et al., 1988). The role of these adhesins in adhesion of C. albicans to polystyrene has been confirmed in this study, since only the $\mathrm{mAbs}$ reactive with some of these components modified the adhesion of C. albicans to polystyrene. Thus, $\mathrm{mAb}$ 3D9, which reacts with an epitope specifically expressed on the germ tube cell wall of $C$, albicans but not expressed on the fibrillar adhesins, showed no effect on adhesion of $C$. albicans to polystyrene. Conversely, $\mathrm{mAb} B 9 \mathrm{E}$, which reacts with the $>200 \mathrm{kDa}$ component, and $\mathrm{mAb} 21 \mathrm{E} 6$, which reacts with components of 68 and $60 \mathrm{kDa}$, influenced the adhesion of $C$. albicans to polystyrene. Interestingly, $\mathrm{mAb}$ $21 \mathrm{E} 6$ was also able to label the high molecular mass components after periodic acid oxidation, suggesting that, in these antigens, the protein epitope reactive with the $\mathrm{mAb}$ is hidden by sugar residues. This situation seems to exist at the cell wall surface also, since, although the $\mathrm{mAb}$ does not label the cell wall surface of $C$. albicans when tested by indirect immunofluorescence (Pontón et al., 1993), there was a strong labelling after periodic acid oxidation (P. A. Ezkurra and co-workers, unpublished).

Attempts to inhibit C. albicans adhesion to host cells or plastic surfaces have been made by various approaches, including antibodies, host proteins, $C$. albicans antigens and antifungals (Critchley \& Douglas, 1987; Edgerton et al., 1993; Epstein et al., 1982; Vuddhhakul et al., 1988). Some mAbs have been used to study the role of cell wall epitopes in the adhesion of $C$. albicans to buccal epithelial cells. Bendel et al. (1993), using mAbs against the $\beta_{2}$ integrin subunit $\alpha_{\mathrm{M}}$, inhibited the adhesion of $C$. albicans by $52 \cdot 4-58 \cdot 2 \%$, and Miyakawa et al. $(1989,1992)$ showed a reduced adherence to buccal epithelial cells of $C$. albicans pretreated with a $\mathrm{mAb}$ against factor $6(\mathrm{mAb}-6)$. In this study, incubation of $C$. albicans with $\mathrm{mAb} B$ 9E, which seems to react with an epitope of antigen 6 (Barturen $\mathrm{et} \mathrm{al \text {, }}$ 1995 ) expressed on the $>200 \mathrm{kDa}$ component of the fibrillar adhesins of $C$. albicans, decreased the adhesion of the fungus to polystyrene. This effect seems to be independent of the strain, since the $\mathrm{mAb}$ inhibited adhesion to polystyrene of two $C$. albicans serotype A and $B$ strains; it may be related to the reduction of germ tube formation by this $\mathrm{mAb}$.

By contrast, incubation of $C$. albicans cells with $\mathrm{mAb} 21 \mathrm{E} 6$ enhanced the adhesion of $C$. albicans 3153 and 1066 strains to polystyrene. Interestingly, the effect was observed in both germ tubes and yeast cells. The effect of mAb $21 \mathrm{E} 6$ on the adhesion of yeast cells was very evident, since the agerminative mutant grown at $37^{\circ} \mathrm{C}$ showed high adhesion levels. The effect of $\mathrm{mAb} 21 \mathrm{E} 6$ on the adhesion of germinating cells was greater when the percentage of germination of the cells was low (40 min). The reasons for this enhancement of adhesion mediated by $\mathrm{mAb} 21 \mathrm{E} 6$ are presently unknown but it does not seem to be related to an increase in cell surface hydrophobicity after incubation 
with $\mathrm{mAb} 21 \mathrm{E} 6$, since pretreatment of $C$. albicans with $\mathrm{mAb} 21 \mathrm{E} 6$ rendered the cells more hydrophilic than those incubated with $\mathrm{mAb} \mathrm{B} 9 \mathrm{E}$ or the controls without antibody. Another possibility is a reorganization of the cell wall fibrillar adhesins induced by $\mathrm{mAb} 21 \mathrm{E} 6$, leading to an exposure of the adhesins on the cell surface. Interestingly, pretreatment of polystyrene with the cell wall fibrillar adhesins enhanced adhesion of the fungus (data not shown). The effect of $\mathrm{mAb} 21 \mathrm{E} 6$ on the adhesion of $C$. albicans to polystyrene implies that the $\mathrm{mAb}$ is able to interact with the cell wall surface. By using an ELISA, we have been able to demonstrate a low reactivity of $\mathrm{mAb}$ $21 \mathrm{E} 6$ with the cell wall surface of both the agerminative mutant and $C$.albicans 3153 germ tubes grown at $37^{\circ} \mathrm{C}$, a reactivity which is likely not to be observed by indirect immunofluorescence due to its lower sensitivity (P. A. Ezkurra and co-workers, unpublished).

In conclusion, both growth phases of $C$. albicans can adhere to polystyrene, although the conditions for this process seem to be different in each phase. Germ tubes can adhere to polystyrene in the absence of $\mathrm{mAb} 21 \mathrm{E} 6$ but the adhesion of the yeast cells was modulated by the mAb. The two methods of adhesion of $C$. albicans to polystyrene might have a role in the colonization of medical implants. In the absence of antibodies against the fibrillar adhesins, a situation which is likely to occur during the first stages of infection, the germ tube may use the fibrillar adhesins to adhere to polystyrene. The production of an antibody response against some cell wall antigens may decrease the adhesion of $C$. albicans, perhaps by reducing filamentation. However, the existence of antibodies like mAb 21E6, which react with the antigens of $>200,200,68$ and $60 \mathrm{kDa}$ present in the fibrillar adhesins, may help the yeast phase to adhere to polystyrene. The different effects shown by the $\mathrm{mAbs}$ studied on the adhesion of $C$. albicans to polystyrene should be taken into consideration when designing strategies to block the adhesion of $C$. albicans to plastic materials with mAbs. However, confirmation of these results with prosthesis or catheter materials must be performed before definitive conclusions can be drawn.

\section{ACKNOWLEDGEMENTS}

We thank L. Campos for photographic assistance and Dr A. Sanz for her help with the statistics. We also thank the reviewers of this manuscript for their useful suggestions. R. San Millan and P. A. Ezkurra were supported by grants from the Dirección General de Investigación Científica y Técnica del Ministerio de Educación y Ciencia. This work was financed by grant PM920108 from the Dirección General de Investigación Científica y Técnica, grant UPV 093.327-EC018/93 from the Universidad del Pais Vasco, and by Contract no. SCI 0361 (EDB) from the Directorate General for Science, Research Development, Commission of the European Communities.

\section{REFERENCES}

Barturen, B., Bikandi, J., San Millan, R., Moragues, M. D., Regúlez, P., Quindos, G. \& Pontón, J. (1995). Variability in expression of antigens responsible for serotype specificity in Candida albicans. Microbiology 141, 1535-1543.
Bendel, C. M., Hostetter, M. K. \& McClellan, M. (1993). Distinct mechanisms of epithelial adhesion for Candida albicans and Candida tropicalis. Identification of the participating ligands and development of inhibitory peptides. J Clin Invest 92, 1840-1849.

Bistoni, F., Vecchiarelli, A., Cenci, E., Pucetti, P., Marconi, P. \& Cassone, A. (1986). Evidence for macrophage-mediated protection against lethal Candida albicans infection. Infect Immun 51, 668-674.

Costerton, J. W., Cheng, K. J., Geesey, G. G., Ladd, T. I., Nickel, J. C., Dasgupta, M. \& Marrie, T. J. (1987). Bacterial biofilms in nature and disease. Annu Rev Microbiol 41, 435- 464.

Critchley, I. A. \& Douglas, L. J. (1987). Isolation and partial characterization of an adhesin from Candida albicans. J Gen Microbiol 133, 629-636.

Cutler, J. E. (1991). Putative virulence factors of Candida albicans. Annu Rev Microbiol 45, 187-218.

Edgerton, M., Scannapieco, F. A., Reddy, M. S. \& Levine, M. J. (1993). Human submandibular-sublingual saliva promotes adhesion of Candida albicans to polymethylmethacrylate. Infect Im mun 61, 2644-2652.

Epstein, J. B., Kimura, L. H., Menard, T. W., Truelove, E. L. \& Pearsall, N. N. (1982). Effects of specific antibodies on the interaction between the fungus Candida albicans and human oral mucosa. Arch Oral Biol 27, 469-474.

Hawser, S. P. \& Douglas, L. J. (1994). Biofilm formation by Candida species on the surface of catheter materials in vitro. Infect Immun 62, 915-921.

Hazen, K. L. \& Hazen, B. W. (1987). A polystyrene microsphere assay for detecting cell surface hydrophobicity within Candida albicans populations. J Microbiol Methods 6, 289-299.

Kennedy, M. J., Rogers, A. L. \& Yancey, R. J. (1989). Environmental alterations and phenotypic regulation of Candida albicans to plastic. Infect Immun 57, 3876-3881.

Kennedy, M. J., Johnson, A. M., Volz, P. A., Neely, A. N. \& Yancey, R. J. (1992). Virulence and adhesive properties of serotype-A and serotype-B of Candida albicans isolated from paediatric burn patients. J Med Microbiol 36, 428-436.

Kimura, L. H. \& Pearsall, N. N. (1980). Relationship between germination of Candida albicans and increased adherence to human buccal epithelial cells. Infect Immun 28, 464-468.

Klotz, S. A., Drutz, D. J. \& Zajic, J. E. (1985). Factors governing adherence of Candida species to plastic surfaces. Infect Immun $\mathbf{5 0}$, 97-101.

Laemmli, U. K. (1970). Cleavage of structural proteins during the assembly of the head of bactetiophage T4. Nature 227, 680-685.

McCourtie, J. \& Douglas, L. J. (1981). Relationship between cell surface composition of Candida albicans and adherence to acrylic after growth on different carbon sources. Infect Immun 32, 1234-1241.

Minagi, S., Miyake, Y., Inagaki, K., Tsuru, H. \& Suginaka, H. (1985). Hydrophobic interaction in Candida albicans and Candida tropicalis adherence to various denture base resin materials. Infect Immun 47, 11-14.

Miyakawa, Y., Kagaya, K., Kuribayashi, T., Suzuki, M. \& Fukazawa, Y. (1989). Isolation and chemical and biological characterization of antigenic mutants of Candida albicans serotype A. Yeast 5, S225-S229.

Miyakawa, Y., Kuribayashi, T., Kagaya, K., Suzuki, M., Nakase, T. \& Fukazawa, Y. (1992). Role of specific determinants in mannan of Candida albicans serotype- $A$ in adherence to human buccal epithelial cells. Infect Immun 60, 2493-2499.

Pontón, J. \& Jones, J. M. (1986). Analysis of cell wall extracts of 
Candida albicans by sodium dodecyl sulfate-polyacrylamide gel electrophoresis and western blot techniques. Infect Immun $\mathbf{5 3}$ 565-572.

Pontón, J., Marot-Leblond, A., Ezkurra, P., Barturen, B., Robert, R. \& Senet, J. M. (1993). Characterization of Candida albicans cell wall antigens with monoclonal antibodies. Infect Immun 61, 4842-4847.

Poulain, D., Tronchin, G., Vernes, A., Popeye, R. \& Biguet, J. (1983). Antigenic variations of Candida albicans in vivo and in vitrorelationships between $\mathrm{P}$ antigens and serotypes. Sabouraudia 21, 99-112.

Rotrosen, D., Edwards, J. E., Gibson, T. R., Moore, J. C., Cohen, A. H. \& Green, I. (1985). Adherence of Candida to cultured vascular endothelial cells: mechanisms of attachment and endothelial cell penetration. J Infect Dis 152, 1264-1274.
Sundstrom, P. M. \& Kenny, G. E. (1984). Characterization of antigens specific to the surface of germ tubes of Candida albicans by immunofluorescence. Infect Immun 43, 850-855.

Tronchin, G., Bouchara, J. F., Robert, R. \& Senet, J. M. (1988). Adherence of Candida albicans germ tube to plastic: ultrastructural and molecular studies of fibrillar adhesins. Infect Immun 56, 1987-1993.

Vuddhhakul, V., McCormack, J. G., Seow, W. K., Smith, S. E. \& Thong, Y. H. (1988). Inhibition of adherence of Candida albicans by conventional and experimental antifungal drugs. I Antimicrob Chemother 21, 755-763.

Received 26 October 1995; revised 27 February 1996; accepted 11 March 1996. 